\section{Inclusion of Acetyl Salicylic Acid and Methyl Jasmonate into the Priming Solution Improves Low-temperature Germination and Emergence of Sweet Pepper}

\author{
Ahmet Korkmaz ${ }^{1}$ \\ Kahramanmaras Sütçü Imam University, Faculty of Agriculture, Department \\ of Horticulture, Kahramanmaras, Turkey, 46060 \\ Additional index words. Capsicum annuum, aspirin, chilling stress, seed treatment, seed \\ storage
}

\begin{abstract}
The effects of incorporating plant growth regulators into the priming solution on low temperature germination and emergence percentage performance of sweet pepper (Capsicum annuum 'Demre') seeds before and after seed storage were investigated. Seeds were primed in $3 \% \mathrm{KNO}_{3}$ solution for 6 days at $25^{\circ} \mathrm{C}$ in darkness containing one of the following: 1, 3, 5, or $10 \mu \mathrm{M}$ methyl jasmonate (MeJA) or $0.05,0.1,0.5$, or $1 \mathrm{mM}$ acetyl salicylic acid (ASA). Following priming, seeds were either immediately subjected to germination and emergence tests at $15{ }^{\circ} \mathrm{C}$ or stored at $4{ }^{\circ} \mathrm{C}$ for 1 month after which they were subjected to germination test at $15^{\circ} \mathrm{C}$. Priming pepper seeds in the presence or absence of plant growth regulators in general improved final germination percentage (FGP), germination rate $\left(\mathbf{G}_{50}\right)$ and germination synchrony $\left(G_{10-90}\right)$ at $15{ }^{\circ} \mathrm{C}$ compared to nonprimed seeds which had an FGP of $44 \%, G_{50}$ of 7.3 days and $G_{10-90}$ of 7.3 days. Priming seeds in $\mathrm{KNO}_{3}$ solution containing $0.1 \mathrm{mM}$ of $\mathrm{ASA}$ resulted in the highest germination percentage $(91 \%)$, fastest germination rate $\left(G_{50}=2.2\right.$ days $)$ and the most synchronous germination $\left(G_{10-90}=6.1\right.$ days $)$. Emergence percentages were the highest for the seeds primed in the presence of $0.1 \mathrm{mMASA}(85 \%)$ and $3 \mu \mathrm{M}$ MeJA $(84 \%)$ while nonprimed seeds had an emergence percentage of $40 \%$. Fastest emergence rates $\left(\mathbf{E}_{50}\right)$ were also obtained from seeds primed in $\mathrm{KNO}_{3}$ supplemented with 3 $\mu \mathrm{MeJA}\left(\mathrm{E}_{50}=15.2\right.$ days $)$ and $0.1 \mathrm{mM}$ ASA $\left(\mathrm{E}_{50}=15.2\right.$ days $)$. Shoot fresh and dry weights of pepper seedlings were significantly affected by priming treatments and priming in the presence of $0.1 \mathrm{mM}$ ASA resulted in highest seedling shoot fresh and dry weights. Although all priming treatments improved germination performance of pepper seeds at $15^{\circ} \mathrm{C}$ following 1 month of storage, inclusion of $0.1 \mathrm{mM}$ ASA into the priming solution resulted in the highest germination percentage $(84 \%)$ and germination rate $\left(G_{50}=3.8\right.$ days). These results indicate that priming seeds in $0.1 \mathrm{mM}$ of ASA or $3 \mu \mathrm{M}$ MeJA incorporated into the KNO solution can be used as an effective method to improve low temperature performance of sweet pepper seeds and that these seeds can be stored for 1 month at $4{ }^{\circ} \mathrm{C}$ and still exhibit improved germination performance at $15^{\circ} \mathrm{C}$.
\end{abstract}

Pepper is a species that requires relatively high soil temperatures for optimal germination and emergence, the optimum being between 25 and $30{ }^{\circ} \mathrm{C}$ (Lorenz and Maynard, 1988). When pepper is seeded directly in the field, soil temperature often can be suboptimal, causing delayed and nonuniform seedling emergence. For example, in the Kahramanmaras province (one of the commercial pepper production areas in Turkey), the mean soil temperature ranges from 10 to $20^{\circ} \mathrm{C}$ at the planting depth on typical seeding dates. Lorenz and Maynard (1988) reported that emergence from $1.2 \mathrm{~cm}$ soil depth took 8 to $9 \mathrm{~d}$ at soil temperatures of 25 to 35 ${ }^{\circ} \mathrm{C}$ and was prevented totally at temperatures $<15^{\circ} \mathrm{C}$. The problem is worsened as the length of time to emergence increases because the probability of soil crust formation becomes

Received for publication 3 May 2004. Accepted for publication 12 July 2004. I would like to thank Iskender Tiryaki for kindly supplying methyl jasmonate.

1E-mail akorkmaz@ksu.edu.tr. greater. Delayed emergence also increases the chances of germinating seeds and seedlings to be infected by damping-off causing pathogens such as Pythium and Rhizoctonia (Olsen and Young, 1998). Thus, obtaining ideal plant stands requires fast and uniform emergence to avoid these problems.

The methods to increase plant's tolerance to stress include genetic engineering, breeding (Vettakkorumakankav et al., 1999), in vitro selection, the use of plant growth regulators (Senaratna et al., 2000) and seed priming (Pill, 1995). Many molecules, for example, jasmonic acid, abscisic acid, salicylic acid, calcium, and polyamines have been suggested as signal transducers and messengers (Klessig and Malamy, 1994). Increasing evidence indicates that plants with high levels of these molecules have increased tolerance to low temperatures, and an increase in endogenous concentrations of these molecules before low temperature exposure might be an essential step to activate a protection mechanism against chilling. For example, soaking tomato and bean seeds in aspirin or acetyl salicylic acid (ASA) solution increased seedling survival during subsequent chilling, high temperature and drought stresses (Senaratna et al., 2000) while inclusion of methyl jasmonate (MeJA) into the priming solution improved watermelon germination and emergence at low temperatures (Korkmaz et al., 2004).

Seed priming is a presowing treatment that involves the controlled hydration of seeds, sufficient to allow pregerminative metabolic events to take place but insufficient to allow radicle protrusion through the seed coat (Pill, 1995). This technique has been used in some vegetable seeds to increase the germination rate, total germination and seedling uniformity, mainly under unfavorable environmental conditions. Beneficial effects of seed priming have been reported for muskmelon by Nascimento and Arago (2004), lettuce by Korkmaz and Pill (2003), tomato by Özbingöl et al. (1998), eggplant by Passam et al. (1989), and pepper by Bradford et al. (1990), O'Sullivan and Bouw (1984), and Rivas et al. (1984). However, most of the pepper seed priming studies have concentrated on improving germination and emergence of jalapeno and tabasco peppers while very little information is available on enhancing the performance of sweet pepper seeds under low temperature stress. The objectives of this study were 1) to investigate if incorporation of plant growth regulators that are known to enhance plant's cold tolerance into priming solution would improve sweet pepper seed germination and emergence at low temperature $\left(15^{\circ} \mathrm{C}\right)$ and 2$)$ to determine whether significant germination enhancement is retained in seeds primed in the presence of growth regulators and stored for 1 month.

\section{Materials and Methods}

Seeds of 'Demre' sweet pepper (Capsicum annuum), all from the same seed lot, were purchased from May Seed Production Cooperation., Bursa, Turkey. The standard germination test was conducted and their initial germination percentage was determined as $94 \%$. All experiments reported in this study were carried out in the beginning of 2004 at Kahramanmaras Sutcu Imam University, Kahramanmaras, Turkey.

Seeds were disinfested in $1 \%$ (active ingredient) sodium hypochlorite for $15 \mathrm{~min}$ to eliminate seedborne microorganisms. Following disinfestation, they were rinsed under running tap water for $1 \mathrm{~min}$ and surface dried by placing them between paper towels for 30 min at room temperature.

Seed germination at low temperature. Priming was accomplished by imbibing $5 \mathrm{~g}$ of seed for $6 \mathrm{~d}$ at $25^{\circ} \mathrm{C}$ in darkness in $3 \% \mathrm{KNO}_{3}$ (Sundstrom and Edwards, 1989) containing one of the following: 1, 3, 5, or $10 \mu \mathrm{M} \mathrm{MeJA(Sigma}$ Aldrich, St. Louis, Mo.), or 0.05, 0.1, 0.5, or 1 mM ASA (Bayer Turk, Istanbul, Turkey). Before incorporating MeJA and ASA into the priming solution, they were first dissolved in a few drops of $99 \%$ ethanol and distilled water was added to make a stock solution. Seeds were placed in covered transparent polystyrene 
germination boxes $(10 \times 10 \times 4 \mathrm{~cm})$ (Ater Plastik, Kocaeli, Turkey) on double layers of filter paper (Whatman \#1) saturated with 10 $\mathrm{mL}$ priming solution supplemented with one of the growth regulators. The priming solutions were changed every other day to maintain a constant osmotic potential. Following priming, the seeds from each box were washed in a sieve and rinsed under running tap water for $1 \mathrm{~min}$ and left to surface dry on paper towels under room conditions $\left(22^{\circ} \mathrm{C}\right.$ and $60 \%$ relative humidity) for $2 \mathrm{~h}$ to make the singulation of the seeds easier. Seeds primed in $3 \% \mathrm{KNO}_{3}$ solution containing no plant growth regulators and nonprimed seeds were also included in the germination test.

Germination test was carried out in darkness in a temperature-controlled incubator held at $15 \pm 0.5^{\circ} \mathrm{C}$. Seeds were placed on two layers of filter paper moistened with $3 \mathrm{~mL}$ of distilled water in covered $5.5-\mathrm{cm}$ petri dishes. Treatments were arranged in completely randomized design with four replications of 50 seeds. Radicle protrusion to $1 \mathrm{~mm}$ was scored as germination. Germination was recorded daily until the numbers stabilized (for $14 \mathrm{~d}$ ) and germinated seeds were removed from the petri dishes. From the total number of seeds germinated, final germination percentage (FGP) and its angular transformation (arcsine $\sqrt{\mathrm{FGP}}$ ), days to $50 \%$ of FGP and days between $10 \%$ and $90 \%$ of FGP were calculated. Time to $50 \%$ of FGP $\left(\mathrm{G}_{50}\right)$ is an inverse measure of germination rate, while time between $10 \%$ and $90 \%$ of FGP $\left(\mathrm{G}_{10-90}\right)$ is considered to be an estimate of the spread of germination, the inverse of germination synchrony.

Seedling emergence at low temperature. Seeds were primed as described above and 25 seeds from each treatment were planted into $1.5 \mathrm{~cm}$ depth in $15 \times 4 \mathrm{~cm}$ (diameter $\times$ height) round plastic cups filled with growth medium consisting of peat and perlite in the ratio of $4: 1$. The cups were watered and placed in a growth chamber (model FOC 225I; Welp Scientifica, Usmate, Italy) at $15 \pm 0.5^{\circ} \mathrm{C}$ and under cool fluorescent lamps providing a photosynthetic photon flux density of $40 \mu \mathrm{mol} \cdot \mathrm{m}^{-2} \cdot \mathrm{s}^{-1}$ for 14 $\mathrm{h} \cdot \mathrm{d}^{-1}$ at the seedling level. The treatments were replicated four times and all the cups were arranged in a randomized complete block design in the growth chamber. Emergence counts (hypocotyl arc visible) were made daily and final emergence percentage (FEP) and its angular transformation (arcsine $\sqrt{\mathrm{FEP}}$ ), days to $50 \%$ of FEP $\left(\mathrm{E}_{50}\right)$, and days between $10 \%$ and $90 \%$ of FEP $\left(\mathrm{E}_{10-90}\right)$ were calculated. Twentyfive days after planting, when the percentage of emergence had stabilized in all treatments, the number of seedlings that emerged and lived (survival ratio), shoot fresh (cut at the medium surface) and dry weights (dried at $65^{\circ} \mathrm{C}$ for $48 \mathrm{~h}$ ) were recorded.

Seed germination at low temperature following storage. Seeds were primed as described above; however, since 5 and $10 \mu \mathrm{M}$ MeJA and 0.5 and $1 \mathrm{mM}$ ASA added to the priming solution significantly decreased germination of pepper seeds at $15^{\circ} \mathrm{C}$ (see Table 1), these concentrations were not used in seed storage experiment.
Following the priming, seeds were rinsed as described above and left to dry on paper towels for $2 \mathrm{~d}$ under room conditions ( 18 to $22^{\circ} \mathrm{C}$ and $50 \%$ to $60 \%$ relative humidity). Nonprimed seeds were also subjected to the same drying conditions. Primed and nonprimed seeds then were placed in screw-top glass bottles and stored in darkness at $4{ }^{\circ} \mathrm{C}$ (refrigerator) for 1 month. At the end of storage, seeds were subjected to germination test at $15 \pm 0.5{ }^{\circ} \mathrm{C}$ as described above. Treatments were arranged in completely randomized design with four replications of 50 seeds.

To determine seed moisture content following storage, four replications of 50 seeds from all treatments were weighed, then placed in glass petri dishes and oven-dried at $130{ }^{\circ} \mathrm{C}$ for $1 \mathrm{~h}$. At the end of $1 \mathrm{~h}$, seeds were weighed again, and their moisture contents expressed as percentages of oven-dry weight were calculated.

Data from all experiments were subjected to analysis of variance and mean separation was performed by Fisher's least significant difference (LSD) test if $\mathrm{F}$ test was significant at $p=0.05$.

\section{Results}

Seed germination at low temperature. Priming pepper seeds regardless of plant growth regulators added to the priming solu- tion significantly improved germination at 15 ${ }^{\circ} \mathrm{C}$ compared to nonprimed seeds which had an FGP of $44 \%$ (Table 1). Inclusion of 0.1 mM ASA into the priming solution resulted in the highest FGP (91\%); however, increasing the concentration of ASA from 0.1 to $1 \mathrm{~mm}$ significantly reduced FGP of pepper seeds. Addition of MeJA to the priming solution also caused significant improvements on the pepper seed germination performance. However, as with the ASA, increasing MeJA concentration added to the priming solution from 1 to 10 $\mu \mathrm{M}$ decreased FGP of pepper seeds from $84 \%$ to $60 \%$. Even though all priming treatments improved the germination rate of pepper seeds compared to the nonprimed seeds $\left(\mathrm{G}_{50}=7.3\right.$ d), the fastest germination rate was obtained from seeds primed in $\mathrm{KNO}_{3}$ supplemented with $0.1 \mathrm{mM}$ ASA $\left(\mathrm{G}_{50}=2.2 \mathrm{~d}\right)$. Among the priming treatments, priming in the presence of $0.05 \mathrm{mM} \mathrm{ASA}\left(\mathrm{G}_{10-90}=6.5 \mathrm{~d}\right)$ and $0.1 \mathrm{mM}$ ASA $\left(\mathrm{G}_{10-90}=6.1 \mathrm{~d}\right)$ were the only treatments that improved the germination synchrony compared to nonprimed seeds $\left(\mathrm{G}_{10-90}=7.3 \mathrm{~d}\right)$. Germination of seeds primed in $10 \mu \mathrm{M}$ MeJA added to the priming solution was the least synchronous $\left(\mathrm{G}_{10-90}=8.2 \mathrm{~d}\right)$.

Seedling emergence at low temperature. Priming also improved FEP of pepper seedlings at low temperature compared to nonprimed seeds which had an FEP of $40 \%$ (Table 2) except that inclusion of $1 \mathrm{mM}$ ASA gave similar

Table 1. Final germination percentage (FGP) and its angular transformation [degrees], days to $50 \%$ of FGP $\left(\mathrm{G}_{50}\right)$, days between $10 \%$ and $90 \%$ of FGP $\left(\mathrm{G}_{10-90}\right)$ of 'Demre' sweet pepper seeds germinated in darkness at $15{ }^{\circ} \mathrm{C}$ following priming for $6 \mathrm{~d}$ at $25{ }^{\circ} \mathrm{C}$ in $3 \% \mathrm{KNO}_{3}$ with various concentrations of methyl jasmonate (MeJA) and acetyl salicylic acid (ASA).

\begin{tabular}{lcccc}
\hline & \multicolumn{2}{c}{ FGP } & $\mathrm{G}_{50}$ & $\mathrm{G}_{10-90}$ \\
Treatment & $(\%)$ & [degrees] & (days) & 6.8 \\
\hline $\mathrm{KNO}_{3}+1 \mu \mathrm{M}$ MeJA & 84 & {$[67]$} & 4.5 & 6.8 \\
$\mathrm{KNO}_{3}+3 \mu \mathrm{M}$ MeJA & 85 & {$[67]$} & 5.2 & 7.3 \\
$\mathrm{KNO}_{3}+5 \mu \mathrm{M}$ MeJA & 79 & {$[63]$} & 5.0 & 8.2 \\
$\mathrm{KNO}_{3}+10 \mu \mathrm{M}$ MeJA & 60 & {$[51]$} & 5.5 & 6.5 \\
$\mathrm{KNO}_{3}+0.05$ mM ASA & 86 & {$[68]$} & 4.9 & 6.1 \\
$\mathrm{KNO}_{3}+0.1$ mM ASA & 91 & {$[73]$} & 2.2 & 7.8 \\
$\mathrm{KNO}_{3}+0.5$ mM ASA & 77 & {$[61]$} & 5.7 & 7.7 \\
$\mathrm{KNO}_{3}+1$ mM ASA & 54 & {$[47]$} & 6.4 & 6.8 \\
$\mathrm{KNO}_{3}$ & 64 & {$[53]$} & 4.4 & 7.3 \\
Nonprimed seeds & 44 & {$[41]$} & 0.6 & 7.3 \\
LSD & & {$[4]$} & $* * *$ & 0.7 \\
Significance & & $* * *$ & $*$ \\
\hline
\end{tabular}

*****Significant at $P \leq 0.05$ or 0.001 , respectively.

Table 2. Final emergence percentage (FEP) and its angular transformation [degrees], days to $50 \%$ of FEP $\left(\mathrm{E}_{50}\right)$, days between $10 \%$ and $90 \%$ of FEP $\left(\mathrm{E}_{10-90}\right)$, survival ratio and shoot fresh and dry weights of 'Demre' sweet pepper seeds emerged at $15{ }^{\circ} \mathrm{C}$ following priming for 6 d at $25{ }^{\circ} \mathrm{C}$ in $3 \% \mathrm{KNO}_{3}$ with various concentrations of methyl jasmonate (MeJA) and acetyl salicylic acid (ASA).

\begin{tabular}{|c|c|c|c|c|c|c|c|}
\hline \multirow[b]{2}{*}{ Treatment } & \multicolumn{2}{|c|}{ FEP } & \multirow{2}{*}{$\begin{array}{c}\mathrm{E}_{50} \\
\text { (days) }\end{array}$} & \multirow{2}{*}{$\begin{array}{l}\mathrm{E}_{10-90} \\
\text { (days) }\end{array}$} & \multirow{2}{*}{$\begin{array}{c}\text { Survival } \\
(\%)\end{array}$} & \multirow{2}{*}{$\begin{array}{c}\text { Shoot } \\
\text { fresh wt } \\
\text { (mg/plant) }\end{array}$} & \multirow{2}{*}{$\begin{array}{c}\text { Shoot } \\
\text { dry wt } \\
\text { (mg/plant }\end{array}$} \\
\hline & $(\%)$ & [degrees] & & & & & \\
\hline$\overline{\mathrm{KNO}_{3}+1 \mu \mathrm{M} \text { MeJA }}$ & 75 & {$[60]$} & 15.6 & 9.4 & 95 & 34.0 & 4.2 \\
\hline $\mathrm{KNO}_{3}^{3}+3 \mu \mathrm{M}$ MeJA & 84 & [66] & 15.2 & 7.6 & 98 & 35.5 & 3.9 \\
\hline $\mathrm{KNO}_{3}^{3}+5 \mu \mathrm{M} \mathrm{MeJA}$ & 73 & [59] & 16.9 & 8.3 & 97 & 30.7 & 4.0 \\
\hline $\mathrm{KNO}_{3}^{3}+10 \mu \mathrm{M} \mathrm{MeJA}$ & 63 & [53] & 17.5 & 8.3 & 92 & 30.6 & 3.8 \\
\hline $\mathrm{KNO}_{3}+0.05 \mathrm{mM} \mathrm{ASA}$ & 74 & [60] & 15.5 & 6.7 & 97 & 34.5 & 4.7 \\
\hline $\mathrm{KNO}_{3}^{3}+0.1 \mathrm{mM} \mathrm{ASA}$ & 85 & [67] & 15.2 & 8.3 & 97 & 38.1 & 4.8 \\
\hline $\mathrm{KNO}_{3}^{3}+0.5 \mathrm{mM} \mathrm{ASA}$ & 74 & [60] & 16.8 & 8.9 & 96 & 29.7 & 4.0 \\
\hline $\mathrm{KNO}_{3}^{3}+1 \mathrm{mM} \mathrm{ASA}$ & 47 & [43] & 17.7 & 8.8 & 96 & 29.8 & 3.8 \\
\hline $\mathrm{KNO}_{3}^{3}$ & 52 & [46] & 17.1 & 8.1 & 90 & 32.8 & 4.0 \\
\hline Nonprimed seeds & 40 & [39] & 20.5 & 7.2 & 95 & 25.3 & 3.4 \\
\hline $\operatorname{LSD}_{0.05}$ & & [6] & 1.2 & --- & --- & 4.4 & 0.5 \\
\hline Significance & & $* * *$ & $* * *$ & NS & NS & $*$ & $*$ \\
\hline
\end{tabular}

NS,*,***N Nonsignificant or significant at $P \leq 0.05$ or 0.001 , respectively. 
Table 3. Final germination percentage (FGP) and its angular transformation [degrees], days to $50 \%$ of FGP $\left(\mathrm{G}_{50}\right)$, days between $10 \%$ and $90 \%$ of FGP $\left(\mathrm{G}_{10-90}\right)$ of 'Demre' sweet pepper seeds germinated in darkness at $15{ }^{\circ} \mathrm{C}$ following priming for $6 \mathrm{~d}$ at $25^{\circ} \mathrm{C}$ in $3 \% \mathrm{KNO}_{3}$ with various concentrations of methyl jasmonate (MeJA) and acetyl salicylic acid (ASA) and 1 month storage at $4{ }^{\circ} \mathrm{C}$.

\begin{tabular}{|c|c|c|c|c|c|}
\hline \multirow[b]{2}{*}{ Treatment } & \multicolumn{2}{|c|}{ FGP } & \multirow{2}{*}{$\begin{array}{c}\mathrm{G}_{50} \\
\text { (days) }\end{array}$} & \multirow{2}{*}{$\begin{array}{l}\mathrm{G}_{10-90} \\
\text { (days) }\end{array}$} & \multirow{2}{*}{$\begin{array}{c}\text { Seed moisture } \\
(\%)\end{array}$} \\
\hline & $(\%)$ & [degrees] & & & \\
\hline$\overline{\mathrm{KNO}_{3}+1 \mu \mathrm{M} \text { MeJA }}$ & 78 & [62] & 5.4 & 5.7 & 7.4 \\
\hline $\mathrm{KNO}_{3}^{3}+3 \mu \mathrm{M}$ MeJA & 79 & [63] & 5.2 & 6.0 & 7.5 \\
\hline $\mathrm{KNO}_{3}+0.05 \mathrm{mM} \mathrm{ASA}$ & 81 & {$[64]$} & 5.0 & 6.1 & 7.8 \\
\hline $\mathrm{KNO}_{3}^{3}+0.1 \mathrm{mM} \mathrm{ASA}$ & 84 & [67] & 3.8 & 6.5 & 7.2 \\
\hline $\mathrm{KNO}_{3}$ & 65 & [54] & 5.1 & 6.4 & 7.5 \\
\hline Nonprimed seeds & 48 & [44] & 7.6 & 6.9 & 7.7 \\
\hline $\operatorname{LSD}_{0.05}$ & & {$[5]$} & 0.7 & --- & --- \\
\hline Significance & & $* *$ & $*$ & NS & NS \\
\hline
\end{tabular}

${ }^{\mathrm{z}}$ Wet weight basis, oven-dried $\left(130{ }^{\circ} \mathrm{C}, 1 \mathrm{~h}\right)$.

NS,*,**Nonsignificant or significant at $P \leq 0.05$ or 0.01 , respectively.

FGP as nonprimed seeds. The highest FEP was obtained when $0.1 \mathrm{mM}$ ASA $(85 \%)$ and $3 \mu \mathrm{M}$ MeJA $(84 \%)$ were added to the priming solution and the emergence of the same treatments was the fastest exhibiting the lowest $\mathrm{E}_{50}$ value of $15.2 \mathrm{~d}$. Compared to lower concentrations, inclusion of the highest concentrations of both growth regulators into the priming solution significantly reduced the emergence percentage and rate of pepper seedlings at low temperature. Moreover, all priming treatments failed to improve the emergence synchrony of pepper seedlings (Table 2 ).

All treatments had $>90 \%$ survival and there were no significant differences among the treatments (Table 2). Both shoot fresh and dry weights of pepper seedlings were affected by priming treatments and priming in the presence of $0.1 \mathrm{mM}$ ASA resulted in highest seedling shoot fresh and dry weights.

Seed germination at low temperature following storage. All priming treatments significantly improved FGP and germination rate of pepper seeds at low temperature following 1 month of storage compared to nonprimed seeds indicating that beneficial effects of priming in the presence of plant growth regulators were retained after 1 month of storage (Table 3). Priming in the presence of $0.1 \mathrm{mM}$ ASA led to the highest FGP $(84 \%)$ and fastest germination $\left(\mathrm{G}_{50}=3.8 \mathrm{~d}\right)$ among all priming treatments. However, neither germination synchrony nor seed moisture content was affected by seed priming followed by storage for 1 month at $4{ }^{\circ} \mathrm{C}$.

\section{Discussion}

Although priming has been reported to improve low temperature germination and emergence of such crops as tomato and asparagus (Pill et al., 1991), muskmelon (Nascimento and Arago, 2004) and sweet corn (Murray, 1990), the effect of priming on low temperature performance of pepper seeds has ranged from no improvement to some advancement in germination percentage and rate. For example, some field emergence trials found little response to seed priming in pepper (Yaklich and Orzolek, 1977), while others observed more rapid and higher percentage germination (O'Sullivan and Bouw, 1984; Rivas et al., 1984) and field emergence (Bradford et al., 1990; Khan et al., 1992). The results of this study indicated that priming sweet pepper seeds in $\mathrm{KNO}_{3}$ supplemented with
$0.1 \mathrm{~mm}$ ASA resulted in $91 \%$ germination and $85 \%$ emergence at $15^{\circ} \mathrm{C}$ which are significantly higher than the germination and emergence of nonprimed and seeds primed in $\mathrm{KNO}_{3}$ only.

Increasing evidence suggests that benzoic acid derivatives such as salicylic acid (SA) or ASA regulate stress tolerance in plants (Lopez-Delgado et al., 1998). These molecules trigger the expression of the potential to tolerate stress rather than having any direct effect as a protectant (Senaratna et al., 2000). Mendoza et al. (2002) reported that imbibing pepper seeds in $0.1 \mathrm{mM}$ SA prevented seedlings from subsequent chilling-induced damage. Senaratna et al. (2003) documented that soaking bean and tomato seeds in $0.1 \mathrm{mM} \mathrm{ASA}$ for $24 \mathrm{~h}$ caused $100 \%$ seedling survival following chilling and heat stresses while none of the control plants survived. The fact that seed imbibition with ASA provided multiple stress tolerance in tomato and bean plants is more consistent with a signaling role for the expression of tolerance rather than a direct effect.

Reductions in germination and emergence percentage caused by ASA concentrations higher than $0.5 \mathrm{mM}$ reported in this study also confirmed the results of Mendoza et al. (2002) and Senaratna et al. (2000) who noted that treating pepper and tomato seeds with 1 mM ASA had an adverse effect on seedling survival following a chilling stress treatment, respectively.

Jasmonates including jasmonic acid and its methyl ester form, methyl jasmonate, have been regarded as endogenous plant growth regulators because of their ubiquitous occurrence in the plant kingdom and their effects on plant growth and development. They are known to induce genes encoding proteinase inhibitors, enzymes involved in flavonoid biosynthesis and lipoxyganase all of which are involved in plant response to stressful conditions and plant defense mechanism (Creelman and Mullet, 1995). When applied exogenously to plants, they seem to have important effects on numerous biological activities one of which is inhibition of seed germination (Sembdner and Parthier, 1993). Inhibition of seed germination by jasmonates was reported in such species as lettuce (Yamane et all., 1981) and amaranth (Kepczynski and Bialecka, 1994). However, the concentration of jasmonates used in these studies were in the range of $10^{-4}$ to $10^{-3} \mathrm{M}$; thus, a specific role of jasmonates as germination inhibitors cannot be assumed from these results due to high concentrations. On the other hand, it was reported that MeJA applied exogenously at the concentration of $10^{-6} \mathrm{M}$ stimulated seed germination in apple (Ranjan and Lewak, 1995) and that priming seed in $\mathrm{KNO}_{3}$ supplemented with $1 \mu \mathrm{M}$ MeJA improved low temperature germination and emergence of watermelon (Korkmaz et al., 2004). Therefore, in studying the potencies of plant growth regulators including jasmonates, a clear discrimination between physiological and supraoptimal concentrations should be made as suggested by Sembdner and Parthier (1993). In this study, lower concentrations ( 1 and $3 \mu \mathrm{M}$ ) of MeJA were found to be the most effective concentrations to improve the low temperature germination and emergence of pepper seeds, and that increasing MeJA concentration from 3 to $10 \mu \mathrm{M}$ reduced germination and emergence.

In seed priming studies, seeds usually are transferred directly from the priming solution to the germination media, generally resulting in very rapid germination compared to nonprimed seeds (Pill, 1995). Since primed seeds have completed phase I (hydration) and II (lag phase) of germination, they only require a favorable water potential gradient for water uptake to begin radicle growth. Primed seeds have the advantage of entering immediately into phase III of germination, while seeds which are dried after priming must repeat phase I and often at least a short phase II before growth occurs (Pill, 1995). In order to maintain high quality in primed seeds for extended storage periods, seeds should be stored at low temperature and low moisture content. In general, storing primed seeds reduces germination or seedling emergence and there are conflicting results on the effect of storage life of primed seeds. For example, slower and less synchronous emergence from primed and dried-back seeds has been reported for such species as asparagus and tomato (Pill et al., 1991) and muskmelon (Oluoch and Welbaum, 1996). On the contrary, Thanos et al. (1989) reported that primed sweet pepper seeds retained their improved vigor after a storage period of 6 months at $5{ }^{\circ} \mathrm{C}$. Korkmaz and Pill (2003) also reported that 2 month storage at $4{ }^{\circ} \mathrm{C}$ did not reduce the performance of primed lettuce seeds.

In this study, although there was a slight reduction in germination percentage and rate of the primed pepper seeds stored for 1 month compared to their germination performance before the storage, seeds from all priming treatments performed better than nonprimed seeds. Higher germination percentages and faster germination rates indicated that beneficial effects of priming were retained in the seeds without any significant loses after a month of storage.

In summary, the result of the present study revealed that inclusion of lower concentrations of ASA $(0.1 \mathrm{mM})$ or MeJA $(3 \mu \mathrm{M})$ significantly improved pepper germination and emergence compared to seeds primed in $\mathrm{KNO}_{3}$ only. Priming with the addition of these plant growth regulators may be an effective way to shorten the time of emergence and increase stand establishment in pepper at low temperatures. 
The fact that aspirin, available everywhere in the world, could be used to prevent crop losses due to low temperature stress may have a significant practical application. Moreover, this study also revealed that beneficial effects of seed priming in the presence of plant growth regulators were retained after 1 month of storage and that primed seeds exhibited improved germination performance at low temperature compared to nonprimed seeds.

\section{Literature Cited}

Bradford, K.J., J.J. Steiner, and S.E. Trawatha. 1990. Seed priming influence on germination and emergence of pepper seed lots. Crop Sci. 30:718-721.

Creelman, R.A. and J.E. Mullet. 1995. Jasmonic acid distribution and action in plants: Regulation during development and response to biotic and abiotic stress. Proc. Natl. Acad. Sci. 92:4114-4119.

Kepczynski J. and B. Bialecka. 1994. Stimulatory effect of ethephon, $\mathrm{ACC}$, gibberellin $\mathrm{A}_{3}$ and $\mathrm{A}_{4}$ on germination of methyl jasmonate inhibited Amaranthus caudatus L. seeds. Plant Growth Regulat. 14:211-216.

Khan, A.A., J.D. Maguire, G.S. Abawi, and S. Ilyas. 1992. Matriconditioning of vegetable seeds to improve stand establishment in early field plantings. J. Amer. Soc. Hort. Sci. 117:41-47.

Klessig, D.F. and J. Malamy. 1994. The salicylic acid signal in plants. Plant Mol. Biol. 26:1439-1458.

Korkmaz, A. and W.G. Pill. 2003. The effect of different priming treatments and storage conditions on germination performance of lettuce seeds. Euro. J. Hort. Sci. 68:260-265.

Korkmaz, A., I. Tiryaki, M.N. Nas, and N. Ozbay. 2004. Inclusion of plant growth regulators into priming solution improves low temperature germination and emergence of watermelon seeds. Can. J. Plant Sci. 84:1161-1165.
Lopez-Delgado, H., J.F. Dat, C.H. Foyer, and I.M Scott. 1998. Induction of thermotolerance in tomato microplants by acetylsalicylic acid and $\mathrm{H}_{2} \mathrm{O}_{2}$. J. Expt. Bot. 49:713-720.

Lorenz, O.A. and D.N. Maynard. 1988. Knott's handbook for vegetable growers. 3rd ed. Wiley, New York.

Mendoza, A.B., H.R. Rodriguez, V.R. Torres, J.H. Davila, J.G.R. Mezquitic, E.B. Tellez, A.S. Rangel, and M.A.B. Garcia. 2002. Seed treatment with salicylates modifies stomatal distribution, stomatal density, and the tolerance to cold stress in pepper seedlings. Proc. Intl. Pepper Conf., Tampico, Mexico, 10-12 Nov..

Murray, G.A. 1990. Priming sweet corn seed to improve emergence under cool conditions. HortScience 25:231

Nascimento, W.M. and F.A.S. Arago. 2004. Muskmelon seed priming in relation to seed vigor. Sci. Agr. 61:114-117.

Olsen, M.W. and D.J. Young. 1998. Damping-off. Univ. Ariz. Coop. Ext. Publ. AZ1029.

Oluoch, M.O. and G.E. Welbaum. 1996. Viability and vigor of osmotically primed muskmelon seeds after nine years of storage. J. Amer. Soc. Hort. Sci. 121:408-413.

O'Sullivan, J. and W.J. Bouw. 1984. Pepper seed treatment for low-temperature germination. Can. J. Plant Sci. 64:387-393.

Özbingöl, N., F. Corbineau, and D. Côme. 1998. Response of tomato seeds to osmoconditioning as related to temperature and oxygen. Seed Sci. Res. 8:377-384.

Passam, H.C., P.I. Karavites, A.A., Papandreou, C.A. Thanos, and K. Georghiou. 1989. Osmoconditioning of seeds in relation to growth and fruit yield of aubergine, pepper, cucumber and melon in unheated greenhouse cultivation. Sci. Hort. 38:207-216.

Pill, W.G. 1995. Low water potential and presowing germination treatments to improve seed quality, p. 319-359. In: A.S. Basra (ed.). Seed quality. Food Products Press, New York.

Pill, W.G., J.J. Fret, and D.C. Morneau. 1991. Germi- nation and seedling emergence of primed tomato and asparagus seeds under adverse conditions. HortScience 26:1160-1162.

Ranjan R. and S. Lewak. 1995. Interaction of jasmonic and abscisic acid in the control of lipases and proteases in germinating apple embryos. Physiol. Plant. 93:421-426.

Rivas, M., F.J. Sundstrom, and R.L. Edwards. 1984. Germination and crop development of hot pepper after seed priming. HortScience 19:279-281.

Sembdner G. and B. Parthier. 1993. The biochemistry and the physiological and molecular action of jasmonates. Annu. Rev. Plant Physiol. Plant Mol. Biol. 33:569-589.

Senaratna, T., D. Touchell, E. Bunn, and K. Dixon. 2000. Acetyl salicylic acid (Aspirin) and salicylic acid induce multiple stress tolerance in bean and tomato plants. Plant Growth Regulat. 30:157-161.

Senaratna, T., D. Merritt, K. Dixon, E. Bunn, D Touchell, and K. Sivasithamparam. 2003. Benzoic acid may act as the functional group in salicylic acid and derivatives in the induction of multiple stress tolerance in plants. Plant Growth Regulat. 39:77-81.

Sundstrom, F.J. and R.L. Edwards. 1989. Pepper seed respiration, germination, and seedling development following seed priming. HortScience 24:343-345.

Thanos, C.A., K. Georghiou, and H.C. Passam. 1989 Osmoconditioning and ageing of pepper seeds during storage. Ann. Bot. 63:65-69.

Vettakkorumakankav, N.N., D. Falk, P. Saxena, and R.A. Fletcher. 1999. A crucial role for gibberellins in stress protection of plants. Plant Cell Physiol. 40:542-548.

Yaklich, R.W. and M.D. Orzalek. 1977. Effect of polyethylene glycol-6000 on pepper seed. HortScience 12:263-264.

Yamane H., H. Takagi, H. Abe, T. Yokota, and N. Takahashi. 1981. Identification of jasmonic acid in three species of higher plants and its biological activities. Plant Cell Physiol. 22:689-697. 